\title{
Market Status and Uses of Aqua-Drugs and Chemicals in Aquaculture at Lakhsmipur, Bangladesh
}

\author{
Shyamal Kumar Paul ${ }^{1 *}$, Fahad Chowdhury ${ }^{1}$, M. Maksud Alam², Priyanka Rani Majumdar ${ }^{1}$ and Md. Robiul \\ Hasan $^{1}$ \\ ${ }^{1}$ Department of Fisheries and Marine Science, Noakhali Science and Technology University, Bangladesh \\ ${ }^{2}$ Deputy Secretary, Ministry of Science and Technology, Bangladesh Secretariat, Dhaka, Bangladesh
}

Submission: April 01, 2021; Published: May 20, 2021

Corresponding author: Shyamal Kumar Paul, Department of Fisheries and Marine Science, Noakhali Science and Technology University, Sonapur, Noakhali, Bangladesh

\begin{abstract}
In order to investigate the present status of commercial aqua drugs and chemicals in the local market and their uses on fish health management. A questionnaire survey was carried out for eight months from August 2016 to March 2017 in three upazilas under the district of Lakhsmipur, Bangladesh. Data were collected through questionnaire interview, personal contact, market survey, Participatory Rural Appraisal like Focus Group Discussion with fifteen fish farmers, fifteen retailers of aqua chemical shops, nine representatives of different pharmaceuticals companies in Lakhsmipur sadar upazila, Raipur upazila and Ramgoti upazila. Nine categories of aqua drugs and chemicals were identified in the study area. In this site, 22 companies were found to be supplying different 51 aqua drugs (under nine categories) in the local market, where ten companies supplying around $79 \%$ of the total drugs and chemicals. Timsen $>$ Virex $>0 x y f l o w>$ Renamycin and Aquamycine $>0$ ossi C $>$ Aqua Boost > Aqua Photo> Ammonil> Geolite gold were the most widely used aqua drugs in the district of Lakhsmipur, Bangladesh. In Lakhsmipur sadar upazila, found 27 aqua drug and chemicals and mostly used of Aqua Photo and Ammonil (9\%) and Oxyflow, Aqua boost, Virex, Timsen (7\%) of each of the total drugs. About 36 aqua drugs and chemicals were reported by the fish farmers at Raipur upazila. Aqua Photo, Oxyflow, and Ammonil were used at 7\% of each of the total cases; Biozyme, Aqua Boost, Ossi C, grow fast, gastrap, Geolite gold, and Rotenone were used at $4 \%$ of each of total the cases; and Bio-pH was used at $3 \%$ of each of the total cases. In this survey, there were 24 different types of aqua drugs and chemicals found in Ramgoti upazila. Ammonil has been used at $11 \%$ of the total cases, while Aqua Boost and Charger gel were used at $6 \%$ of each of the total cases. In the investigated area, various types of diseases such as Dropsy, EUS (epizootic ulcerative syndrome), red spot and different parasitic diseases were found to occur in Pangus (Pangasianolan hypophthalmus), Tilapia (Oreochromis nilotica), Sharputi (Puntius sarana), Rui (Labeo rohita), Mrigal (Cirrhinus mrigala), Thai koi (Anabas testudineus), Shing (Heteropneustes fossilis). Susceptible months of disease outbreak in the study area were August, November, December, January, February, and March. During the field observation, many issues with aqua-drugs were discovered, including farmers' lack of understanding of drug application, an insufficient withdrawal time, and some negative effects on fish and human health.
\end{abstract}

Keywords: Aqua drug; Fish health management; Market status; Fish farmer; Aqua chemicals

\section{Introduction}

Freshwater aquaculture in Bangladesh primarily consists of pond aquaculture, especially polyculture of both native and exotic species; coastal aquaculture, on the other hand, primarily consists of shrimp farming. Aquaculture production systems in Bangladesh are mostly extensive and extended extensive, with some semiintensive and, in a few instances, intensive systems. Aquaculture is the world's fastest-growing food-producing industry, growing at a rate faster than any other animal-based food-producing sector. It has been extended, diversified, intensified, and technologically advanced in Bangladesh as well. In Bangladesh, with the growth of aquaculture, there has been a growing trend in the use of aquamedicines. Aqua-medicine has only recently been introduced in order to meet the growing demand in aquaculture [1]. Chemicals in aquaculture can be categorized based on their intended use, the form of species being cultured, the life cycle stage for which they are used, the culture method, the strength of the culture, and the people who use them [2].

Aqua-medicines are used by farmers for a variety of purposes, including pond building, health management, soil and water 
management, enhancement of natural aquatic productivity, transportation of live organisms, feed formulation, manipulation and enhancement of reproduction, and growth promotion.

To ensure proper fish health care, drugs and chemicals are used extensively in aquaculture. There are many reasons for using drugs in aquaculture, including reducing the entry of pathogenic organisms into the culture field, reducing the proliferation of pathogenic organisms, reducing the stressful condition on fish health, reducing, or preventing disease outbreaks, and treating disease [3]. Lime, rotenone, various inorganic and organic fertilizers, salt, dipterex, antimicrobials, potassium permanganate, copper sulphate, formalin, sumithion, melathion, and other chemicals are widely used in Bangladesh aquaculture [4].

About 400 aqua-medicine are now produced by 100 pharmaceuticals in Bangladesh. Various type of those aquamedicine was marketed by innumerable company which were used in aquaculture activities like as water quality management, improve dissolve oxygen, growth promoter, antibiotics, and disinfectants. Farmers have used these substances as a disinfectant to prevent contamination and/or pathogen in their pond. A host of antibiotics, pesticides and other chemicals have been used to prevent and manage infections and likely to produce antibioticresistant bacteria, persistence of pesticides and other substances harmful to aquatic ecosystems and to create human health threats. The emphasis of international aquaculture is therefore on how the ecological environment of aquaculture can be improved. Now, in aquaculture, researchers are attempting to use probiotic bacteria to enhance the water quality by balancing bacterial populations in water and reducing pathogens [5]. This latest approach (ecological aquaculture) is increasingly given to researchers and has taken a significant step forward. The indiscriminate application of aqua drugs or chemicals also leads to problems such as drug resistance, tissue residue, adverse biodiversity effects on the animal, human and environmental effects.

Effect of aqua-drug and antibiotic on shrimp health are well known [6]. The export of shrimp from Bangladesh has also been prohibited due to presence of antibiotic residue [7]. The ban placed the shrimp export industry in the country under severe pressure and caused major market disturbances that had already recovered with the required actions. Most farmers do not have the proper doses and application to cause ecologic degradation in some areas to the extent that water quality is inadequate for aquaculture [8]. Farmers without understanding their effectiveness had been aware of the application of these aqua medicines. This creates serious problems in the aquatic environment and causes low aquaculture production. Once again, fish diseases are a major challenge to optimal production and are a restrictive factor in Bangladesh's economic performance. The study also found some problems with the use of such chemicals because farmers were unfamiliar with the use of chemical compounds, sufficient dosage, method of use and indiscriminate use. Most studies were done on the use of aqua drug and their impact of fish health and production. But did not study on the market share of aqua drug and companies and fish health management in Lakhsmipur district, Bangladesh. Thus, the present study was carried out to describe the status of aqua drug and their use in aquaculture.

\section{Materials and Methods}

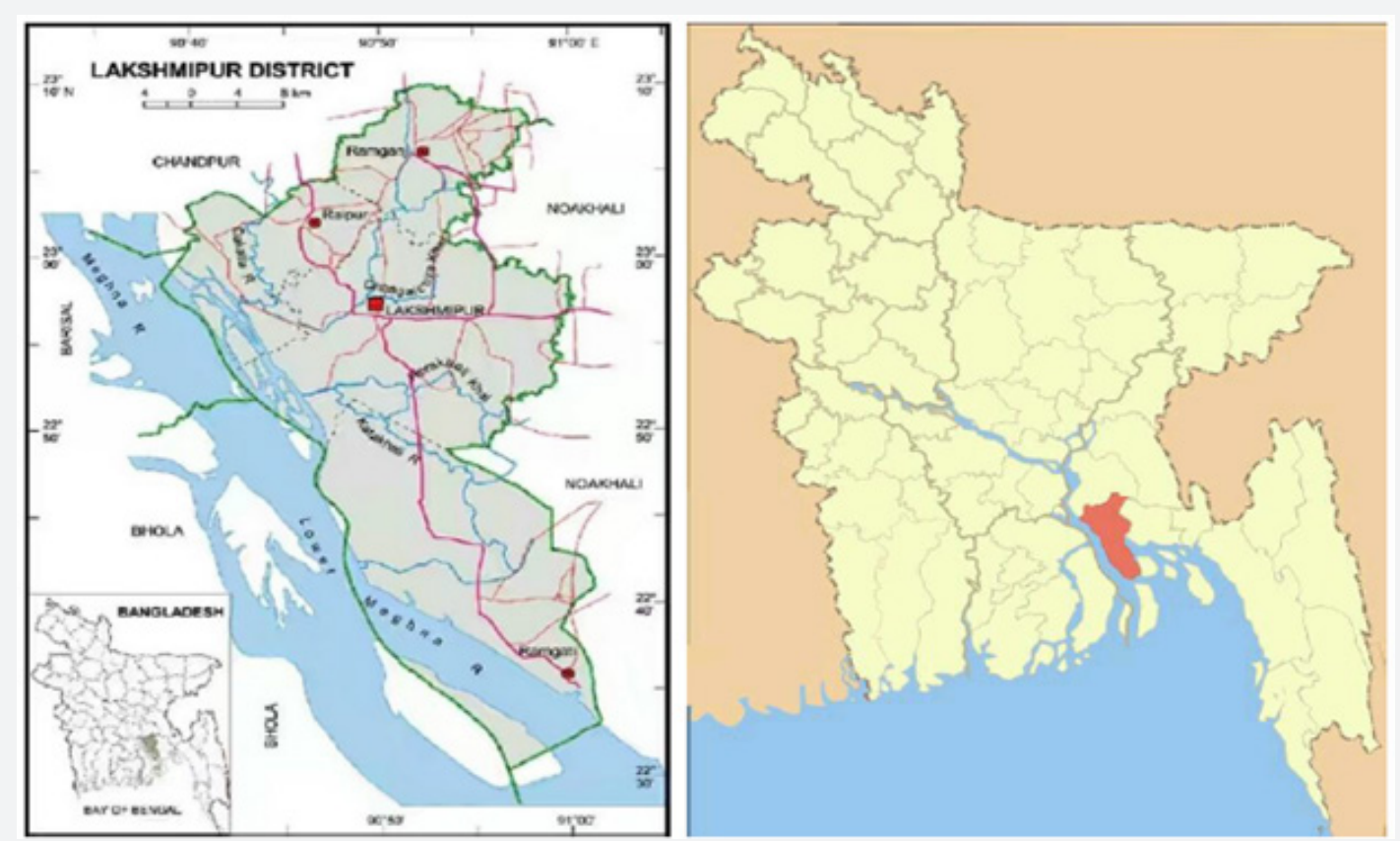

Figure 1: Study area; Map of Lakhsmipur and site in the Map of Bangladesh. 
The present study was carried out in some upazilas like as in Lakhsmipur sadar upazila, Raipur upazila, Ramgoti upazila under the district of Lakhsmipur in Bangladesh (Figure 1). The study was carried out eight months from August 2016 to March 2017 with a view to finding out the present status of aqua drugs and chemicals used in fathomed area. Considering the intensity of fish farming of those areas, fifteen fish farmers, fifteen retailers of animal or fish medicine and nine representative of pharmaceuticals companies were visited at Lakhsmipur sadar upazila, Raipur and Ramgoti upazila. Data were randomly collected from retailers, fish farmers, representatives covering the selected study area. Field level data were validated by the crosscheck interviews with the key informants. The information was gathered using a questionnaire interview. The questionnaire consisted of open and closed questionnaires. There has been a number of preliminary questions. Chemical names, purpose-of-use active ingredients, method of application and length of dosing, source, environmental impacts, health effects and productivity were the main subjects of this questionnaire.

A simple random sampling procedure accompanied the interview. Also accumulated by industry analysis and Participatory Rural Assessment (PRA) with chemical sellers or animal health suppliers, members, and fishermen, as well as by Focus Group
Discussion (FGD). Two-third portion of the data were collected from retailers of aqua chemical shops present in the study areas. The primary and secondary data were used during the analysis. Various survey techniques were followed, and combination of several techniques were adopted for gathering data. Primary data were collected through personal interviews with farm owners, retailers, and representative of different pharmaceuticals companies. Drugs and chemicals trade name, chemical compound, purpose of use, dose, price, related companies of the available drugs and chemicals were considered important elements during investigating fish farms, culture pond and aqua chemical shops.

For the collection of secondary data Journals, textbooks, newspaper etc. were used. Moreover, appropriate government and non-government organizations as like Upazila Fisheries Office were also visited. For the verification of field level information different private aqua consulting agencies or farms were also visited. The data were analyzed and summarized in tablets, which is why the collected data was carefully checked and summarized prior to the actual tabulation. This was achieved. Tables and charts related to this have also been developed and data is finally presented in tabular and graphical form. The data analysis was carried out using Microsoft Excel 2013 (FlowChart 1).

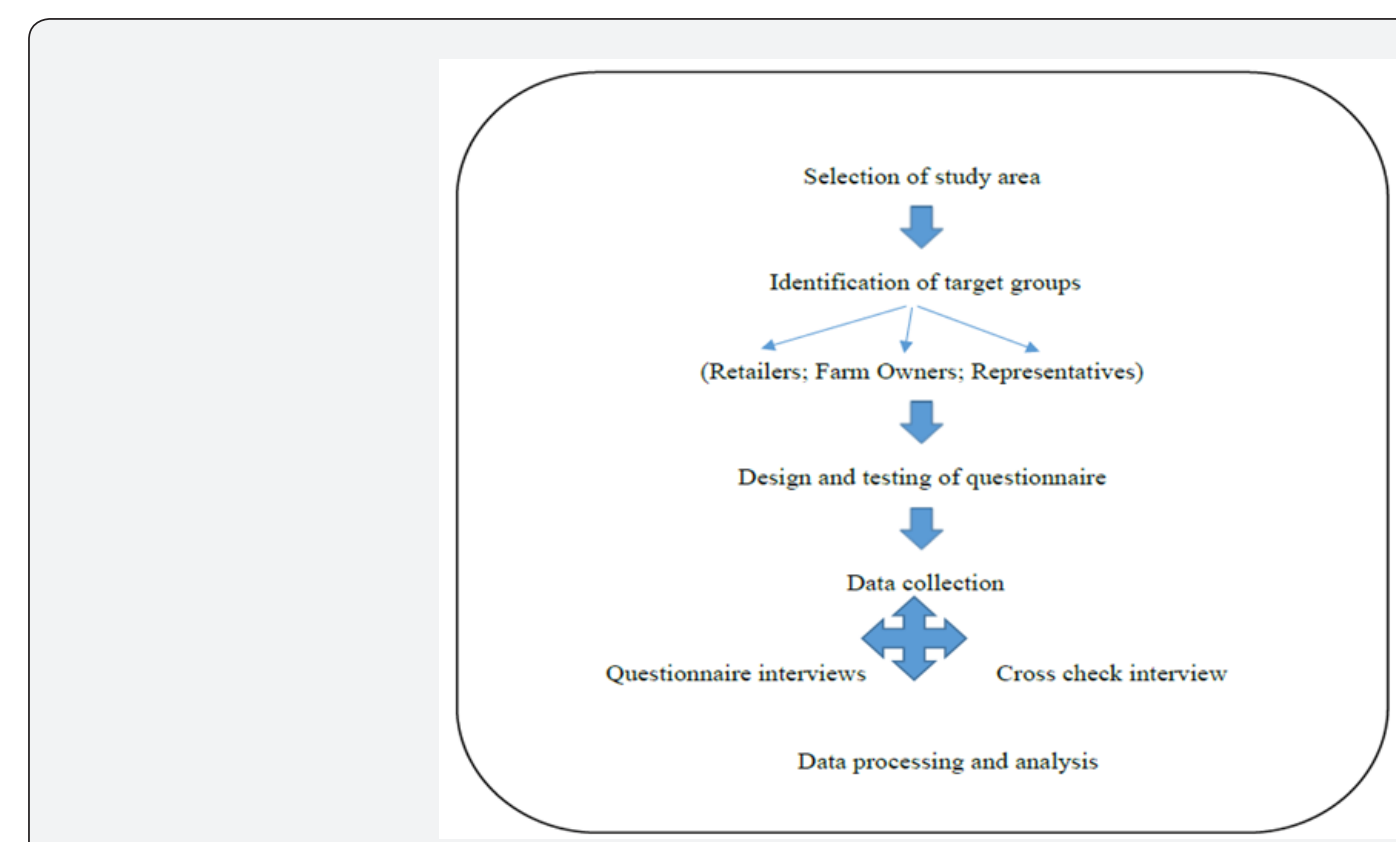

Flowchart 1: Design of survey in this study.

\section{Results}

\section{Commonly Available Aqua Medicines in Lakhsmipur Sadar Upazila, Raipur Upazila, and Ramgoti Upazila}

In Lakhsmipur sadar upazila, commonly available aqua medicines were Oxyflow, Bio-Ox, Oxymax (oxygen supplier); Timsen, Virex, Sumithion (disinfectant); Aqua Boost, Charger gel (growth promoter); Renamycin, Renaquine, Renamox, Doxioxy, Bactitab (antibiotics); Ammonil, Matrix (gas reducer); Virex, Potash, Lime, Malachite green, Methylene blue (for disease treatment); Ossi C, Revit C (vitamin); Zeolite gold, Geotox, rotenone (for pond preparation and water quality management); Aqua photo, Pond plus (probiotics) (Table 1). 
In Raipur upazila, commonly available aqua medicines were Oxyflow, Oxymore, Oxygold (oxygen supplier); Timsen, Sumithion, Virex, Bactisol-80, Pond safe (disinfectant); Megavit aqua, Aqua boost, ACmix super-Fish, Panvit aqua (growth promoter); Renamycin, Amoxifish, Amoxivet, Oxysestin, Bactitab, Oxy Dox F (antibiotics); Gastrap, Ammonil (gas reducer); Ablaze, Vime clean, Eco-solution. Formalin, Salt, Malachite green, Potash, Lime (for disease treatment; Ossi C, Grow fast, Silvermil (vitamin); Zeolite gold, Rotenone, Bio-pH (for pond preparation and water quality management); Aqua photo, Biozyme (probiotics) (Table 1).

Table 1: Commonly available aqua medicines in Lakhsmipur Sadar Upazila, Raipur Upazila, Ramgoti Upazila.

\begin{tabular}{|c|c|c|c|}
\hline $\begin{array}{l}\text { Categories of available Aqua } \\
\text { drugs and Chemicals }\end{array}$ & Lakhsmipur Sadar Upazila & Raipur Upazila & Ramgoti Upazila \\
\hline Oxygen supplier & Oxyflow, Bio-Ox, Oxymax & Oxyflow, Oxymore, Oxygold & Oxyflow, Oxygold, Bio-Ox \\
\hline Disinfectant & Timsen, Virex, Sumithion & $\begin{array}{l}\text { Timsen, Sumithion, Virex, Bactisol-80, } \\
\text { Pond Safe }\end{array}$ & Timsen, Virex, Sumithion \\
\hline Growth promoter & Aqua Boost, Charger gel & $\begin{array}{l}\text { Megavit Aqua, Aqua Boost, Acmix su- } \\
\text { per-Fish, Panvit aqua }\end{array}$ & Aqua Boost, Charger gel \\
\hline Antibiotics & $\begin{array}{l}\text { Renamycin, Renaquine, Renamox, } \\
\text { Doxioxy, Bactitab }\end{array}$ & $\begin{array}{l}\text { Renamycin, Amoxifish, Amoxivet, Oxyses- } \\
\text { tin, Bactitab, Oxy Dox F }\end{array}$ & $\begin{array}{l}\text { Renamycin, Aquamycine, } \\
\text { Renamox }\end{array}$ \\
\hline Gas Reducer & Ammonil, Matrix & Gastrap, Ammonil & Ammonil \\
\hline Disease Treatment & $\begin{array}{l}\text { Virex, Potash, Lime, Malachite } \\
\text { green, Methylene Blue }\end{array}$ & $\begin{array}{l}\text { Ablaze, Vime Clean, Eco-solution, Formalin, } \\
\text { Salt, Malachite green, Potash, Lime }\end{array}$ & $\begin{array}{l}\text { Potash, Lime, Virex, Mel- } \\
\text { athion }\end{array}$ \\
\hline Vitamins & Ossi C, Revit C & Ossi C, Growfast, Silvermil & Ossi C, Revit C, Growfast \\
\hline $\begin{array}{l}\text { Pond preparation and water quali- } \\
\text { ty management }\end{array}$ & Zeolite gold, Geotox, Rotenone & Zeolite gold, Rotenone, Bio-pH & $\begin{array}{l}\text { Zeolite gold, Rotenone, } \\
\text { Mega-geo plus }\end{array}$ \\
\hline Probiotics & Aqua photo, Pond plus & Aqua Photo, Biozime & $\begin{array}{l}\text { Aqua Photo, Pond plus, } \\
\text { Biozime }\end{array}$ \\
\hline
\end{tabular}

In Ramgoti Upazila, commonly available aqua medicines were Oxyflow, Oxygold, Bio-Ox (oxygen supplier); Timsen, Virex, Sumithion (disinfectant); Aqua Boost, Charger gel (growth promoter); Renamycin, Aquamycine, Renamox (antibiotics); Ammonil (gas reducer); Potash, Lime, Virex, Melathion (for disease treatment); Ossi C, Revit C, Growfast (vitamins); Zeolite gold, Rotenone, Megageo plus (for pond preparation and water quality management); Aqua photo, Pond plus, Biozyme (probiotics) (Table 1).

\section{Name of Top Ten Aqua Drugs and Chemicals in Lakhsmipur district}

In this study, farmers often used ten different drugs in their pond under the district of Lakshmipur. Timsen is the first option for destroying bacteria, Virex for disinfection, Oxyflow for oxygen supply, Renamycin and Aquamycine for antibiotics, Ossi C for vitamins, Aqua Boost for growth, Aqua Photo for probiotics, Ammonil for gas reduction, and Geolite gold for pond preparation and water quality control. (Table 2).

Table 2: Top 10 aqua drugs mostly used by the farmers in ponds at Lakhsmipur district

\begin{tabular}{|c|c|c|c|c|c|c|}
\hline SL & $\begin{array}{l}\text { Trade } \\
\text { name }\end{array}$ & Active ingredient & Purpose of use & Dose & Source & Price (tk.) \\
\hline 1 & Timsen & $\begin{array}{l}\mathrm{n} \text {-alkyl dimethyl benzyl } \\
\text { ammonium chloride- } 40 \%\end{array}$ & Killing microbes & $\begin{array}{l}1^{\text {st }} \text { dose: } 80 \mathrm{~g} / 33 \mathrm{dec} \\
2^{\text {nd }} \text { dose: } 50 \mathrm{~g} / 33 \mathrm{dec}\end{array}$ & $\begin{array}{l}\text { Eon Animal } \\
\text { Health Products } \\
\text { Ltd. }\end{array}$ & $238 / 50 \mathrm{~g}$ \\
\hline 2 & Virex & $\begin{array}{l}\text { Per oxy monosulfate, } \\
\text { sodium hydrochloroisocy- } \\
\text { anorate }\end{array}$ & Disinfectant & $100-200 \mathrm{~g} / 33 \mathrm{dec}$ & $\begin{array}{l}\text { ACI Livestock } \\
\text { and Fisheries }\end{array}$ & $120 / 100 \mathrm{~g}$ \\
\hline 3 & $\begin{array}{l}\text { Oxy- } \\
\text { flow }\end{array}$ & $10 \%$ hydrogen peroxide & Oxygen supplier & $\begin{array}{l}250-350 \mathrm{~g} / \text { acre. In case of } \\
\text { high deficiency } 500 \mathrm{~g} / \text { acre }\end{array}$ & $\begin{array}{l}\text { Novartis Animal } \\
\text { Health Ltd. }\end{array}$ & $650 / \mathrm{kg}$ \\
\hline 4 & $\begin{array}{l}\text { Rena- } \\
\text { mycin }\end{array}$ & Oxytetracycline & Antibiotic & $50 \mathrm{mg} / \mathrm{kg}$ body weight & Renata Ltd. & $820 / \mathrm{kg}$ \\
\hline 5 & $\begin{array}{l}\text { Aqua- } \\
\text { mycine }\end{array}$ & $\begin{array}{l}\text { Oxytetracycline hydrochlo- } \\
\text { ride }\end{array}$ & Antibiotic & $1-2 \mathrm{~g} /$ feed & $\begin{array}{l}\text { ACI Livestock } \\
\text { and Fisheries }\end{array}$ & $80 / 100 \mathrm{~g}$ \\
\hline 6 & Ossi-C & $\begin{array}{l}\text { Oxolinic acid, bitaglucan, } \\
\text { vit-c }\end{array}$ & Vitamins & $4-5 \mathrm{~g} / \mathrm{kg}$ feed for $5-7$ days & $\begin{array}{l}\text { Fishtech (BD) } \\
\text { Ltd. }\end{array}$ & $330 / 100 \mathrm{~g}$ \\
\hline 7 & $\begin{array}{l}\text { Geolite } \\
\text { gold }\end{array}$ & $\begin{array}{l}\mathrm{SiO} 2, \mathrm{Al} 2 \mathrm{O} 3, \mathrm{Fe} 2 \mathrm{O}, \mathrm{TiO} 2 \\
\text { MgO, etc. }\end{array}$ & $\begin{array}{c}\text { Pond preparation and } \\
\text { water quality manage- } \\
\text { ment }\end{array}$ & $\begin{array}{l}200-250 \mathrm{~g} / \mathrm{dec} \text { (repeat } 30- \\
40 \text { days interval) }\end{array}$ & $\begin{array}{l}\text { Fishtech (BD) } \\
\text { Ltd. }\end{array}$ & $425 / 10 \mathrm{~kg}$ \\
\hline
\end{tabular}




\section{Oceanography \& Fisheries Open access Journal}

\begin{tabular}{|c|c|c|c|c|c|c|}
\hline 8 & $\begin{array}{c}\text { Aqua } \\
\text { Boost }\end{array}$ & Organic acid, B-Glucan & Growth promoter & $500 \mathrm{~g} / \mathrm{MT}$ feed & $\begin{array}{c}\text { Novartis Animal } \\
\text { Health Ltd. }\end{array}$ & $300 / \mathrm{kg}$ \\
\hline 9 & $\begin{array}{c}\text { Aqua } \\
\text { photo }\end{array}$ & Bacillus subtilis & Probiotics & $50 \mathrm{ml} / \mathrm{dec}$. & $\begin{array}{c}\text { ACI Animal } \\
\text { Health Ltd. }\end{array}$ & $300 /$ liter \\
\hline 10 & $\begin{array}{c}\text { Am- } \\
\text { monil }\end{array}$ & $\begin{array}{c}\text { Yucca plant extract Bacillus } \\
\text { subtilis }\end{array}$ & Gas removal & $200 \mathrm{gm} /$ acre & $\begin{array}{c}\text { Novartis Animal } \\
\text { Health Ltd. }\end{array}$ & $195 / \mathrm{kg}$ \\
\hline
\end{tabular}

\section{Market Share of Aqua Chemicals in the Study Area}

By consulting with retailers and fish farmers, the study discovered that 51 drugs and chemicals were available in the study area. According to the use of chemicals by farmers, Timsen,
Oxyflow, Virex, Renamycin, Aquamycine, Ossi C, sumithion, Geolite gold, Potash, and Aqua boost were the most commonly available. Timsen was the most common among these, accounting for $23 \%$ of the total, which is why most farmers used it as a disinfectant (Figure 2).

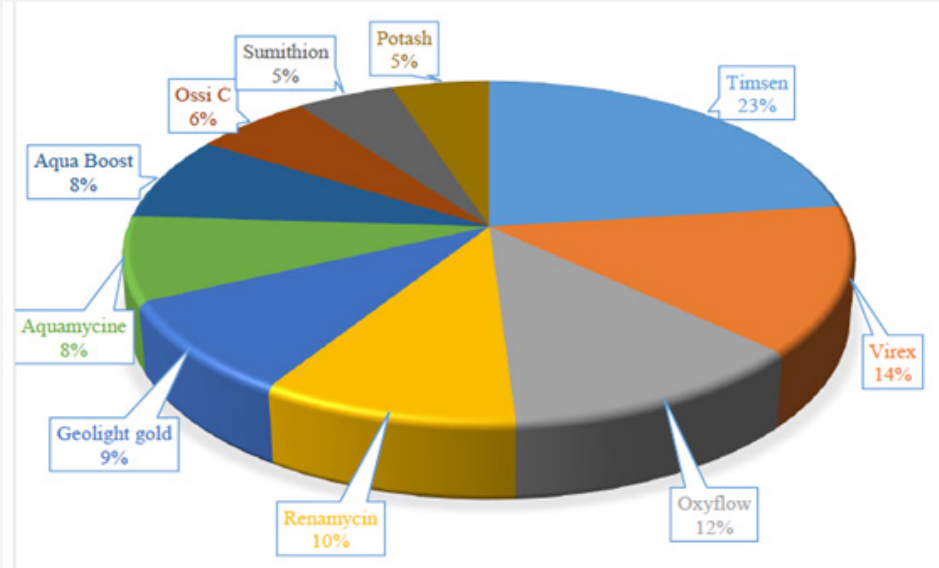

Figure 2: Most available chemicals and aqua drugs in the study area.

\section{Market Share of Aqua Pharmaceuticals Companies}

In the study area, there were 22 companies being supplied different drugs and chemicals and about $79 \%$ of the total products were supplied by ten companies. The study showed that these were Fish tech (BD) Ltd. (23\%), Novartis Animal Health Ltd.
(15\%), ACI Livestock and Fisheries (7\%), Renata Ltd. (5\%), Eon Animal Health products Ltd. (5\%), Acme Pharmaceuticals Ltd. (5\%), Square Pharmaceuticals Ltd. (5\%), Opsonin Pharma Ltd. (4\%), Sigma agro-vat Ltd. (5\%), Fish Care Pharmaceuticals Ltd. (5\%) and the remaining 21\% were supplied by the other 12 companies including local non brand companies. (Figure 3)

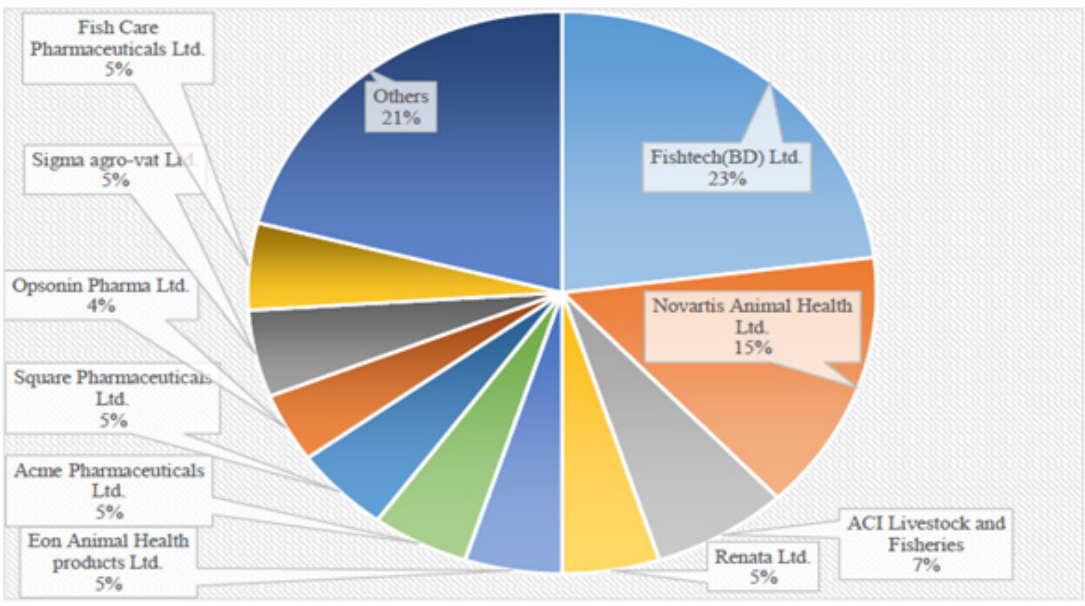

Figure 3: Market share of aqua pharmaceuticals companies. 


\section{Aqua Drugs and Chemicals Frequently used by the Farmers}

Farmers primarily used oxygen suppliers to raise oxygen levels in water bodies, according to the study. Farmers in the study region mainly used Oxyflow, Bio-Ox, and Oxy gold. Oxyflow (Novartis Animal Health Ltd.) was used in $61 \%$ of the total cases, Bio-Ox (ACI Animal Health Ltd.) in $20 \%$ of the total cases, and Oxygold (Fish tech BD Ltd.) in 19\% of the total cases (Figure 4). Timsen, Virex, and Sumithion were found to be the most commonly used disinfectants by farmers in the study. Timsen (Eon Animal Health Products Ltd.) was used in 68\% of the total cases, Virex (ACI Animal Health Ltd.) in 17\%, and Sumithion (Samco Ltd.) in 15\% (Figure 5). The study showed that Aqua Boost, Megavit aqua, Charger gel were mostly used by the farmers in the study area. Aqua Boost (Novartis Pharmaceuticals Ltd.) was used in 55\%, Megavit aqua (Novartis Pharmaceuticals Ltd.) used in $28 \%$ and Charger gel (Fish tech BD Ltd.) used in $17 \%$ of the total cases (Figure 6). Mostly used chemicals as antibiotics in the study area were Renamycin, Aquamycine, Renamox. Renamycin (Renata Ltd.) and used in 46\%, Aquamycine (ACI Livestock and Fisheries) in 35\% and Renamox (Renata Ltd.) in 19\% of the total cases (Figure 7).

Figure 4: Chemicals used for oxygen supply.

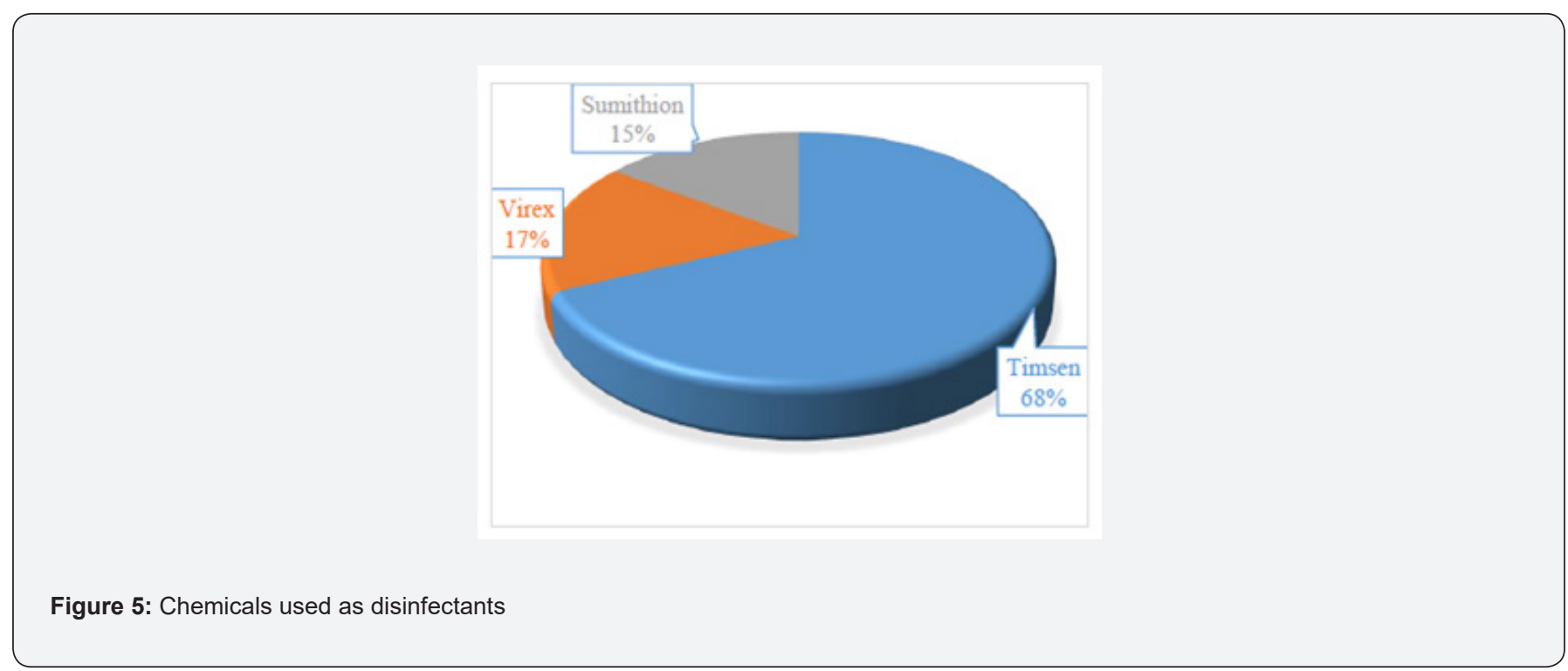

In the study region, farmers used gas reducers such as Ammonil, Gastrap, and Matrix. Ammonil (Novartis Animal Health Ltd.) was used $60 \%$ of the time, Gastrap (Square Pharmaceuticals Ltd.) was used $24 \%$ of the time, and Matrix (Eon Pharmaceuticals Ltd.) was used $16 \%$ of the time (Figure 8). Farmers in the study area used vitamins such as Ossi C, Revit C, and Growfast. Ossi C (Fish tech BD Ltd.) was used in $62 \%$ of the total cases, Revit $\mathrm{C}$
(Opsonin Pharma Ltd.) was used in $20 \%$ of the total cases, and Growfast (Rals Agro Ltd.) was used in $18 \%$ of the total cases (Figure 9). Aqua photo, Biozyme, and Pond plus were the most commonly used probiotics in the study region. Aqua photo (ACI Animal Health Ltd.) was used in $54 \%$ of the total cases, Biozyme (Fish tech BD Ltd.) was used in $26 \%$ of the total cases, and Pond plus (Fish tech BD Ltd.) was used in $20 \%$ of the total cases 
(Figure 10). The study discovered that Geolight gold, Rotenone, and Megageo plus were the most commonly used chemicals for pond preparation and water quality management. Geolight gold (Fish tech BD Ltd.) was used in $43 \%$ of the total cases, Rotenone
(Samco Ltd.) was used in $29 \%$ of the total cases, and Megageo plus (ACI Livestock and Fisheries) was used in $28 \%$ of the total cases (Figure 11).

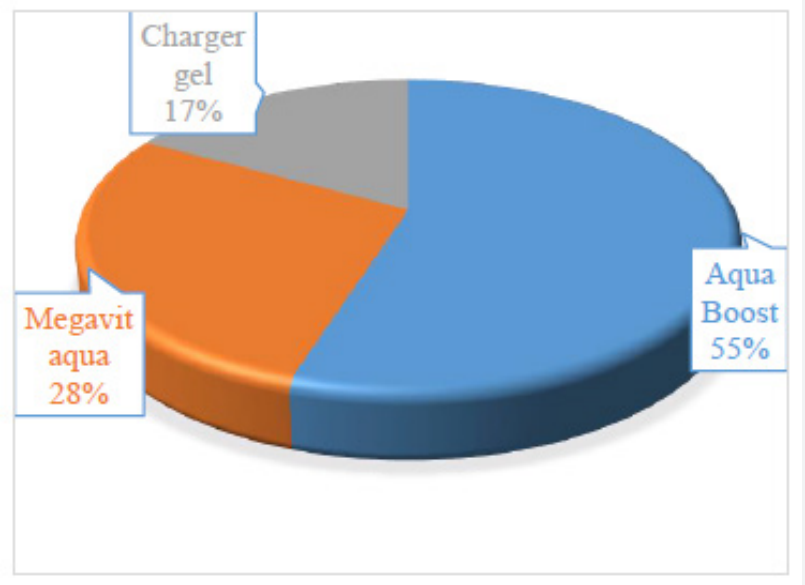

Figure 6: Chemicals used for Growth Promoter.

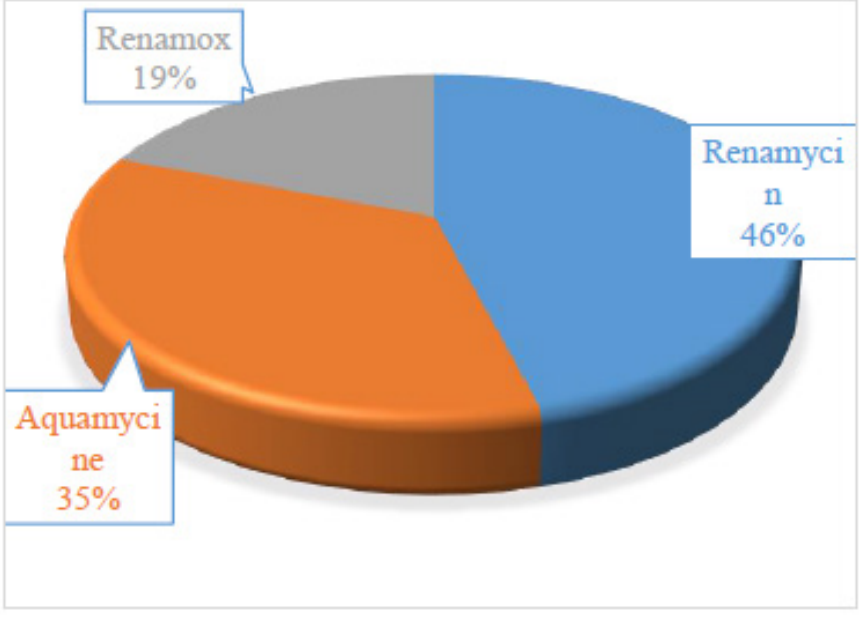

Figure 7: Chemicals used as Antibiotics.

\section{Aqua Drugs and Chemicals used by the Farmers at Lakhsmipur Sadar Upazila}

From the study, it has been found that there were 27 in number aqua drugs and chemicals at Lakhsmipur Upazila. Among these aqua drugs Aqua Photo and Ammonil were used in 9\%; Oxyflow and Aqua boost were used in 7\%; Virex (disinfectant), Timsen, Charger gel, Revit C, Geolite gold were used in 5\%; Pond plus, Bio-0x, Oxymax, Sumithion, Renamycin, Renaquine, Renamox, Doxioxy, Bactitab, Matrix, Virex (for disease treatment), Potash,
Lime, Melachite green, Methylene Blue, Geotox, Rotenone were used in $2 \%$ of the total cases (Figure 12).

\section{Aqua Drugs and Chemicals used by the Farmers at Raipur Upazila}

According to the findings of the current study, farmers in Raipur Upazila used 36 different aqua medicines and chemicals. Among those drugs, Aqua Photo, Oxyflow and Ammonil were used in 7\% of each; Biozyme, Aqua Boost, Ossi C, Growfast, gastrap, Geolite gold, Rotenone were used in $4 \%$ of each; Bio-pH 
used in 3\% of each; Oxymore, Oxygold, Timsen, Sumithion, Virex, Bactisol-80, Pond safe, Megavit aqua, Acmix super-fish, Panvit aqua, Renamycin, Amoxifish, Amoxivet, Oxysestin, Melachite green, Potash, Lime and Silvermil were used in 2\% of each; Oxy Doxy F, Bactitab, Ablaze, Vime clean, Eco-solution, salt and formalin were used in $1 \%$ of each (Figure 13).

Figure 8: chemicals used as Gas Reducer.

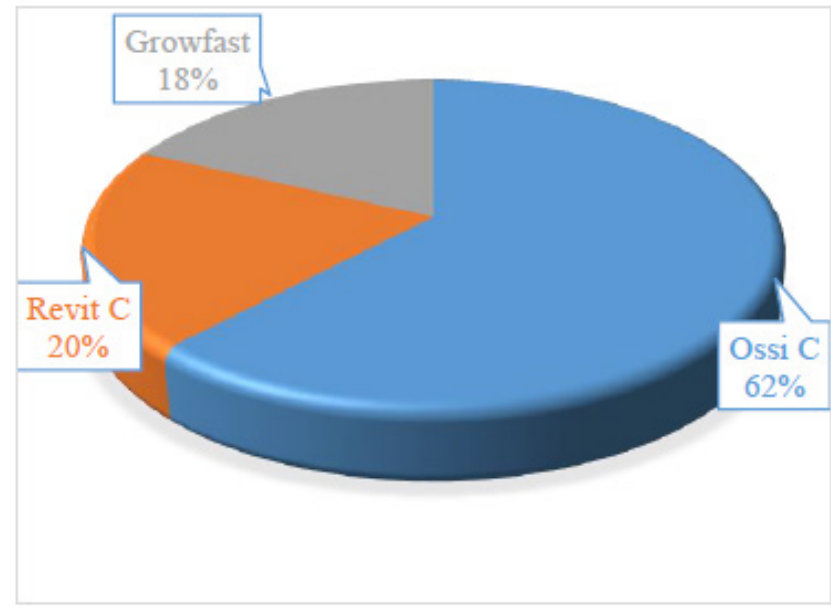

Figure 9: Chemicals used as Vitamins

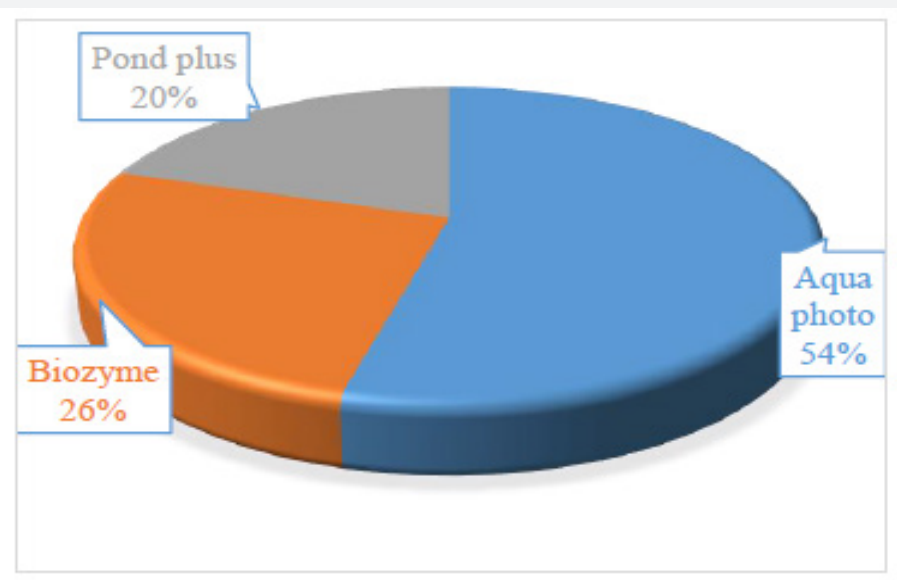

Figure 10: Chemicals used as Probiotics. 


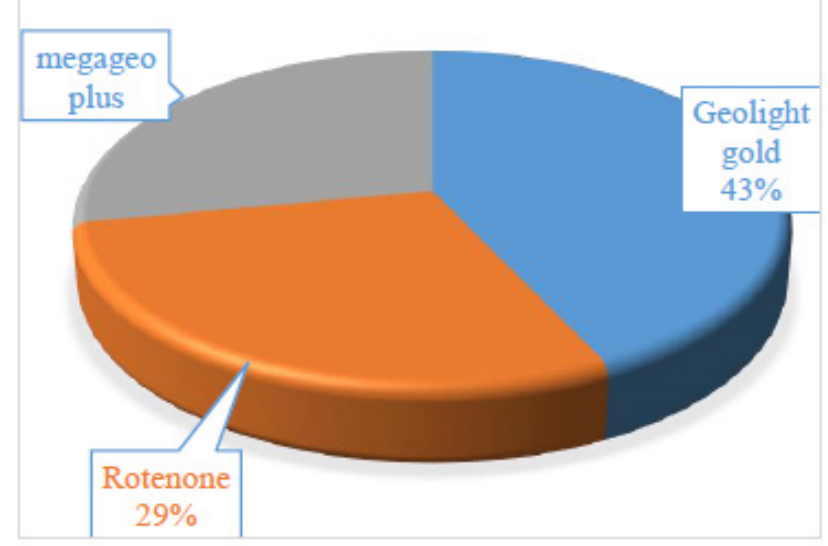

Figure 11: chemicals used for pond preparation and water quality management.

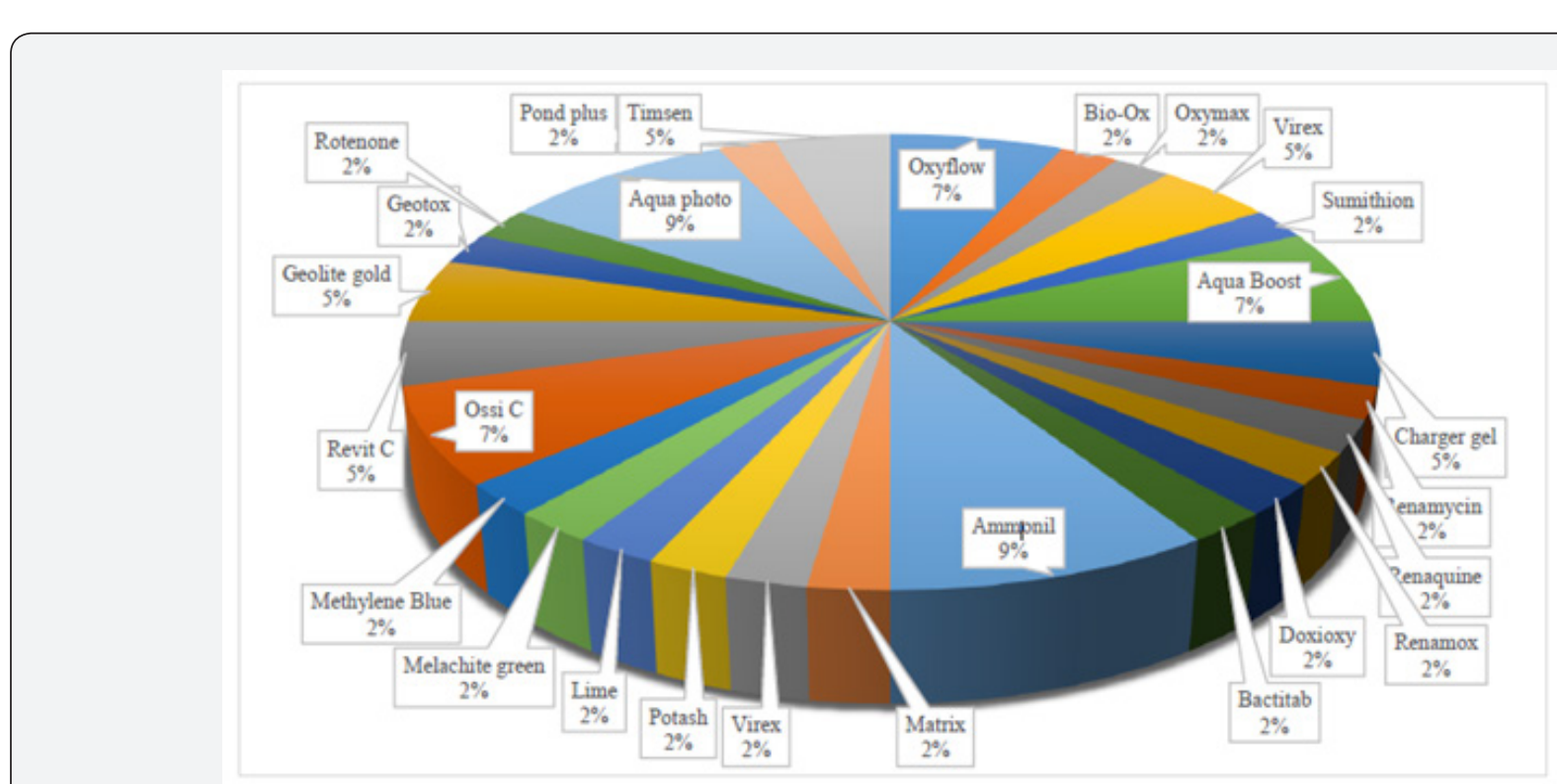

Figure 12: Aqua drugs and chemicals used by the farmers at Lakhsmipur Sadar Upazila.

\section{Aqua Drugs and Chemicals used by the Farmers at Ramgoti Upazila}

From the study, it has been showed that there were 24 in numbers of aqua drugs, and chemicals found at Ramgoti Upazila. Among these drugs, Ammonil used in 11\%; Aqua Boost and Charger gel are used in 6\% of each; Renamycin, Aquamycine, Potash, Lime, Ossi C, Revit C, Geolite gold, Megageo plus, Aqua Photo, Biozyme, Oxyflow, Bio-Ox, Timsen and virex were used in $4 \%$ of each; Growfast, Rotenone and Pond plus were used in 3\% of each; Renamox, Melathion, Oxygold and Sumithion were used in $2 \%$ of each (Figure 14).

\section{Diseases Occurred in the Study Area}

In the study area, the following diseases were observed: Gill rot, Dropsy, Tail red disease, EUS, Body hemorrhage in various freshwater fish species. Often found in shrimp species was ciliated protozoan disease. Melachite green, disinfectant and vitamin combinations, antibiotics, vime clean were used for various treatments for various diseases (Table 3).

\section{Effect of Aqua Drugs and Chemicals on Fish Health}

EUS affected Tilapia were treated by farmers with antibiotics as Renamycin, Renamox and Oxysestin having $80-85 \%$ recovery. Ammonia poisoning was seen with Labeo rohita, Gibelion catla treated by regular water check and maintenance with a result of $90 \%$ recovery. Renamycin and Zeolite Gold were used as drugs by the farmers with a result of $85 \%$ recovery. Farmers reported that Indian major carp found to be susceptible with Lernaeasis having $80 \%$ recovery. Oxyflow, Oxy life, Bio-oxy were used by the farmers as the treatment on oxygen deficiency of Labeo rohita 


\section{Oceanography \& Fisheries Open access Journal}

and Gibelion catla having 90\% recovery. Without reasonable symptoms Heteropneustes fossilis, Clarias batrachus were the most susceptible species having 30\% prevalence. Deletix and

Timsen were used by the farmers as the treatment on white spot disease of Heteropneustes fossilis, Clarias batrachus resulting $80 \%$ prevalence and Heteropneustes fossilis was mostly susceptible to white spot in Nov-Feb among the affected species (Table 4).

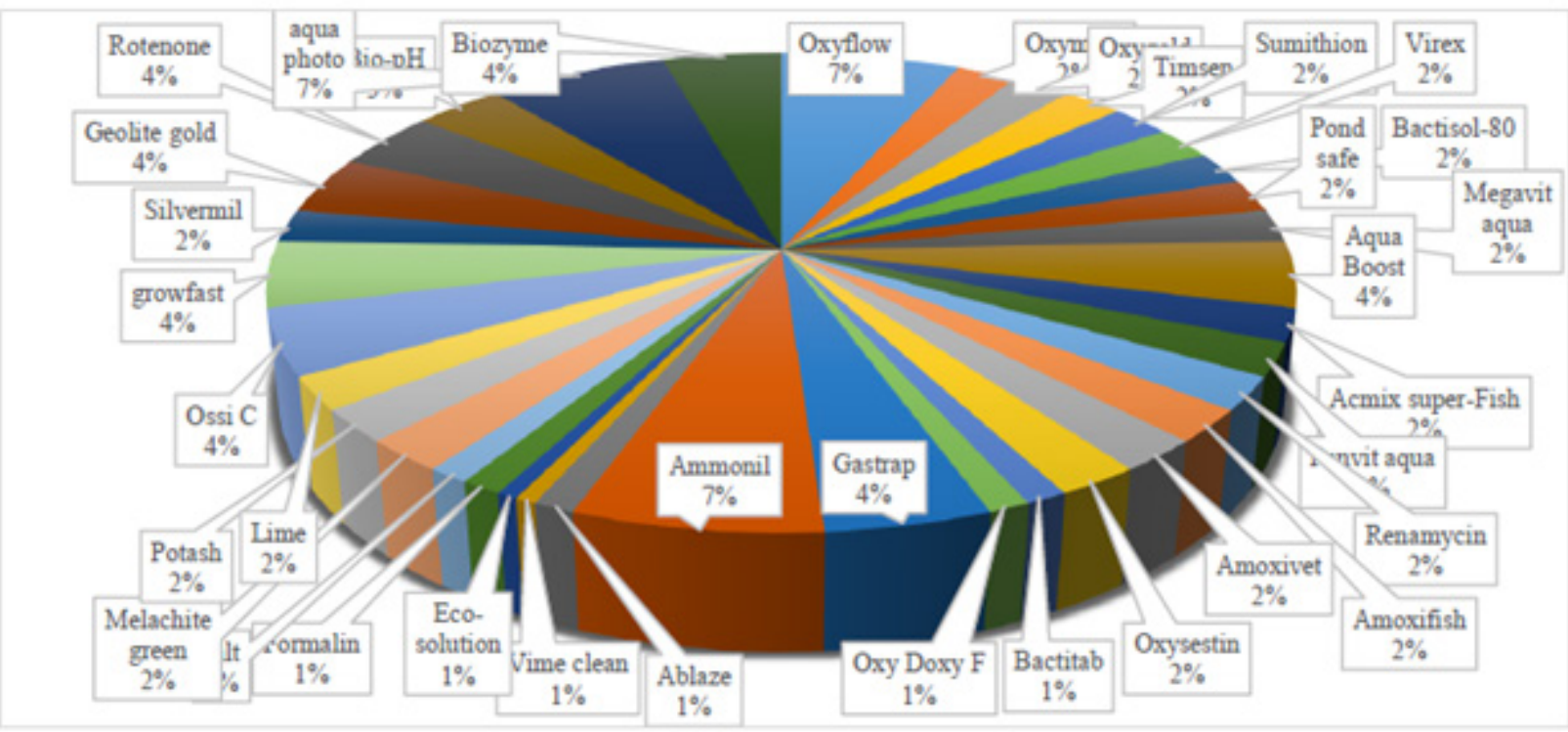

Figure 13: Aqua drugs and chemicals used by the farmers at Raipur Upazila.

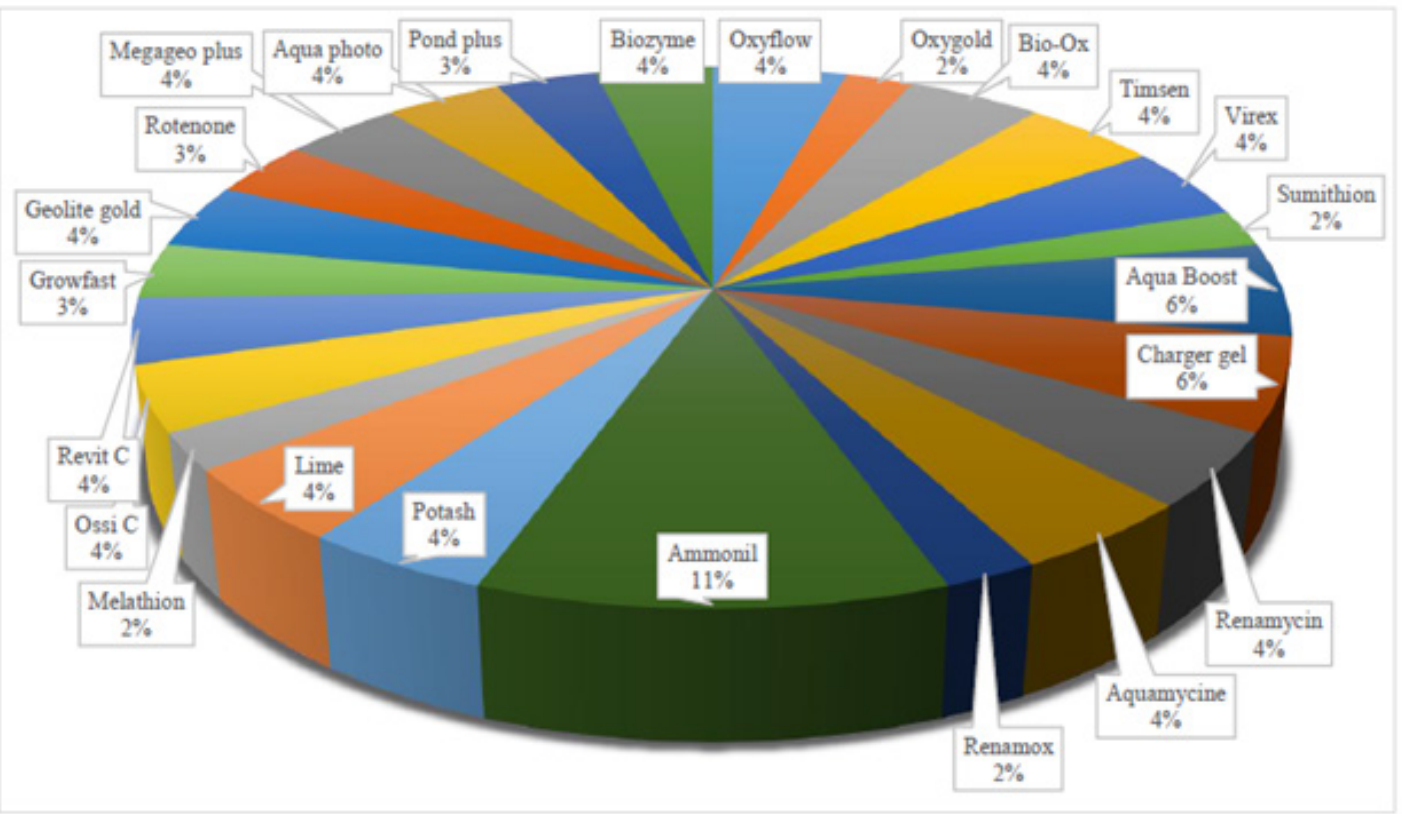

Figure 14: Aqua drugs and chemicals used by the farmers at Ramgoti Upazila.

\section{Discussion}

With the intensification of aquaculture practices in the recent years in Bangladesh, uses of chemicals were increased.
In aquaculture, the external inputs required for successful fish production is chemical which has been used in various forms for centuries [9]. In aquaculture activities, the benefits of chemical 
usage are many. Aqua drugs and chemicals are used to develop water quality, dissolve oxygen level, as disinfectants, disease treatment, antibiotics and growth promoter and are widely recognized in Bangladesh. The present study was carried out to know the present status of aqua drugs and chemicals in three Upazilas of Lakhsmipur district and impact of aqua-drug on fish health. In this study, it was found that mostly nine different categories of commercial aqua drugs and chemicals were used by farmer for different aquaculture purposes like disease treatment, disinfectants, growth promotion, pond preparation, antibiotics, gas removal, oxygen supplier, vitamins, and probiotics.

Table 3: Diseases occurred in the study area

\begin{tabular}{|c|c|c|}
\hline Name of the disease & Affected fishes & Most common treatment used by the farmers \\
\hline Ciliated protozoan disease & Macrobrachium rosenbergii & Malachite green at the rate of $1.2 \mathrm{ppm}$ \\
\hline Dropsy & $\begin{array}{l}\text { Labeo rohita, Cirrhinus mrigala, Gibelion catla, Panga- } \\
\text { sius, Cyprinus carpio }\end{array}$ & Combination of disinfectant and vit-C (Ossi C, Revit $\mathrm{C}$ etc.) \\
\hline Body hemorrhage & $\begin{array}{l}\text { Oreochromis niloticus, Pangasius pangasius, Cyprinus } \\
\text { carpio }\end{array}$ & Combination of disinfectant and antibiotic \\
\hline $\begin{array}{l}\text { EUS (Epizootic Ulcerative } \\
\text { Syndrome) }\end{array}$ & $\begin{array}{l}\text { Labeo rohita, Cirrhinus mrigala, Gibelion catla, Panga- } \\
\text { sius, Cyprinus carpio }\end{array}$ & Combination of disinfectant (Timsen, pond safe, Potash) \\
\hline Gill disease & $\begin{array}{l}\text { Labeo rohita, Cirrhinus mrigala, Gibelion catla, Panga- } \\
\text { sius, Cyprinus carpio }\end{array}$ & Combination of disinfectant and antibiotic \\
\hline Tail rot disease & $\begin{array}{c}\text { Anabas cobojius, Heteropneustes fossilis, Mystus } \\
\text { vittatus }\end{array}$ & Combination of disinfectant and antibiotic \\
\hline Anchor problem & Fry of the fishes & Combination of disinfectant and Vime clean \\
\hline
\end{tabular}

Table 4: Effect of aqua drugs and chemicals on fish health and recovery of disease in the study area.

\begin{tabular}{|c|c|c|c|c|c|}
\hline $\begin{array}{l}\text { Disease preva- } \\
\text { lence }(\%)\end{array}$ & Species & Clinical sign & $\begin{array}{l}\text { Commercial chemicals and aqua } \\
\text { drugs used }\end{array}$ & $\begin{array}{l}\text { Affected } \\
\text { months }\end{array}$ & Recovery \\
\hline $\begin{array}{l}\text { Ammonia poison- } \\
\text { ing }(60 \%)\end{array}$ & $\begin{array}{l}\text { Labeo rohita, Gibelion } \\
\text { catla, Cirrhinus mrigala, }\end{array}$ & Bloody gills, gasping for air & $\begin{array}{c}\text { Regular water testing and mainte- } \\
\text { nance }\end{array}$ & January & $90 \%$ \\
\hline $\begin{array}{l}\text { Oxygen deficien- } \\
\text { cy }(70 \%)\end{array}$ & $\begin{array}{l}\text { Labeo rohita, Gibelion } \\
\text { catla }\end{array}$ & $\begin{array}{l}\text { Gasping at the surface with their } \\
\text { mouth }\end{array}$ & Oxylife, Oxyflow, Bio- oxy & December & $90 \%$ \\
\hline $\begin{array}{l}\text { Exophthalmia } \\
(75 \%)\end{array}$ & Oreochromis niloticus & $\begin{array}{l}\text { Unusually bulging of one or both } \\
\text { eyes }\end{array}$ & $\begin{array}{l}\text { OTC medications for bacterial infec- } \\
\text { tions and parasites }\end{array}$ & December & $70 \%$ \\
\hline Lernaeasis (20\%) & $\begin{array}{l}\text { Labeo rohita, Gibelion } \\
\text { catla, Cirrhinus mrigala }\end{array}$ & $\begin{array}{l}\text { fishes are restless and rub against } \\
\text { the side and bottom of the pond }\end{array}$ & KMn04: Pond treatment at $4 \mathrm{ppm}$ & January & $80 \%$ \\
\hline White spot (80\%) & $\begin{array}{l}\text { Heteropneustes fossilis, } \\
\text { Clarias batrachus }\end{array}$ & $\begin{array}{l}\text { Small white spot-on fish, fish will } \\
\text { scratch against gravel and rocks, } \\
\text { damage to the gills and swelling of } \\
\text { abdomen }\end{array}$ & $\begin{array}{l}\text { Deletix at the rate of } 25-30 \mathrm{ml} / \mathrm{ac} \\
\text { for } 4 \text { feet water depth Timsen at the } \\
\text { rate of } 1^{\text {st }} \text { dose: } 80 \mathrm{mg} / 33 \mathrm{dec} \\
2^{\text {nd }} \text { dose: } 50 \mathrm{gm} / 33 \mathrm{dec}\end{array}$ & $\begin{array}{l}\text { Novem- } \\
\text { ber-Feb- } \\
\text { ruary }\end{array}$ & $80 \%$ \\
\hline Cataracts $(40 \%)$ & $\begin{array}{l}\text { Oreochromis niloticus, } \\
\text { Gibelion catla }\end{array}$ & White or gray fungus on eyes & OTC medication for fungus & December & $75 \%$ \\
\hline EUS (70\%) & $\begin{array}{l}\text { Labeo rohita, Gibelion } \\
\text { catla, Cirrhinus mrigala, } \\
\text { Ctenopharyngodon } \\
\text { idella }\end{array}$ & $\begin{array}{c}\text { Red spot-on body surface, lesion on } \\
\text { body surface }\end{array}$ & Use antibiotics & August & $85 \%$ \\
\hline EUS (60\%) & Puntius sarana & Red spot-on body surface & $\begin{array}{l}\text { Renamycin at the rate of } 50 \mathrm{mg} / \mathrm{kg} \\
\text { body weight }\end{array}$ & August & $80 \%$ \\
\hline EUS (60\%) & Labio rohita & Red spot-on body surface & $\begin{array}{l}\text { Renamycin at the rate of } 50 \mathrm{mg} / \mathrm{kg} \\
\text { body weight }\end{array}$ & August & $80 \%$ \\
\hline $\begin{array}{l}\text { Columnaris } \\
\quad(70 \%)\end{array}$ & $\begin{array}{c}\text { Cyprinus carpio, Anabas } \\
\text { cobojius }\end{array}$ & $\begin{array}{l}\text { Skin, fin rays and operculum covered } \\
\text { with white spores }\end{array}$ & $\begin{array}{c}\text { Geolite gold at the rate of } 200- \\
250 \mathrm{gm} / \mathrm{dec} \text { Timsen at the rate of } \\
1^{\text {st }} \text { dose: } 80 \mathrm{gm} / 33 \mathrm{dec} 2^{\text {nd }} \text { dose: } \\
50 \mathrm{gm} / 33 \mathrm{dec}\end{array}$ & $\begin{array}{l}\text { November } \\
\text {-March }\end{array}$ & $80 \%$ \\
\hline
\end{tabular}

In the study area, 51 products of 22 animal health companies were found to market at field level. Seven categories of aquamedicines and chemicals were used by small fish farmers, commercial fish farmers and hatchery owners in Shatkhira District [10]. Eight different categories of aqua drugs and chemicals were found to use in shrimp farming activities in coastal belt of 
Bangladesh as oxygen suppliers, disinfectants, growth promoters, antibiotics, pond preparatory, gas removal, insect killers and microbe killers [1]. Six categories of aqua drugs and chemicals were found to be used by fish farmers and hatchery owners for water quality management, disinfectants, disease treatment, antibiotics, and growth promoter [11].

In the present study, it was observed that about 10 antibiotics (specially oxytetracycline, hlorotetracycline, amoxicillin, cotrimoxazole, sulphadiazine, azithromysin) with different trade names were used by the farmer. Antibiotics used only for the treatment of bacterial diseases that occurred in the study area.

It was found in the present study that antibiotics were used indiscriminately without knowing the exact reasons of disease. Some farmers did not follow the described dosages for treatment. It is widely recognized that the excessive use of antibiotics contributes the development of resistant strains of bacteria [12]. Most of the farmers used chemicals and antibiotics indiscriminately without knowing their mode of action, doses, and appropriate procedure of application [13]. Most of the large fish farm owners used aqua drugs and chemicals by knowing their dose, purpose, and application. But in small farms drugs were used indiscriminately. Rasul et al. 2017 [14] reported that 18 trade names of antibiotics were found and frequently used the trade name of antibiotics like as Oxy-Dox-F and Renamycin by the freshwater aqua farmers in Sylhet, Bangladesh.

From the present study, it was found that Megavit aqua, Aqua Boost, ACI mix super-Fish, Charger gel, Panvit aqua were highly available aqua drugs used as growth promoter. Faruk et. al., [8] found that Megavit aqua, Aqua Boost, Aqua savor, Vitamin premix, Fibosoel, Growfast, Orgavit aqua, Aq-cell, Aqgrow-g, Fish vita plus, Aq grow- 1, Growmax, Nature aqua gp, Vitamix, F aqua, ACI mix and many more chemicals have been used as growth promoters to increase production. Geolite gold, Geotox, Megageo plus, Rotenone, Bio-pH were readily available aqua drugs used for pond preparation and water quality management in the study area. Similar products were found by Faruk et al. 2008 and Chowdhury et al. 2015 [8,15]. Timsen, Virex, Bactisol-80, Sumithion, Pond safe were seen in the study area used as disinfectants. EDTA, Bleaching, Timsen, Emsen, Water clear, Pathocide, Omicide, Lenocide, Microdine-iodine 20\%, Formalin, BKC, Efinol, were found as disinfectants by Faruk et al. 2008 [8].

Vitamins help to increase body weight, growth, and disease resistance power of fish. Ossi C, Revit C, Growfast, Silvermil were found as vitamins in the present study area. Large farm owners which contain own feed formulation technology maintain balanced diet by mixing vitamins with feed. Whereas small farm owners cannot maintain balanced diet because of using supplementary feed. Alam et. al. 2014 [10] reported that three brand name of vitamin premix (Acimix Super-fish, Megavit-Aqua, Square aqumix) were found in Sathkhira, Bangladesh. From the present study, it has been found that to increase disease resistance power a little amount probiotics were found to be used. Aqua photo, Biozyme, Pond plus were readily available probiotics in the present study area. Chowdhury et al. 2015 [15] reported that other probiotics products (Biomax, Probio aqua LQ, Square aquamix) were found in Zakiganj, Sylhet.

In the study area, about $79 \%$ of different drugs and chemicals were supplied by ten companies. The study showed that these were Fish tech (BD) Ltd. (23\%), Novartis Animal Health Ltd. (15\%), ACI Livestock and Fisheries (7\%), Renata Ltd. (5\%), Eon Animal Health products Ltd. (5\%), Acme Pharmaceuticals Ltd. (5\%), Square Pharmaceuticals Ltd. (5\%), Opsonin Pharma Ltd. (5\%), Sigma agro-vat Ltd. (4\%), Fish Care Pharmaceuticals Ltd. (5\%) and the remaining $21 \%$ were supplied by the 12 companies including local non brand companies. There are fifty-two pharmaceutical companies have been recorded to market around 300 products and most of the products have been marketed from different countries like USA, Thailand, Malaysia, Belgium, and China etc. [15]

The present study revealed that commercial aqua drugs have some positive impact on fish health management and disease treatment at farmer's level. It was observed that farmers of the selected areas got good results in disease treatments by applying single or combinations of various aqua-drugs and chemicals. In some cases, after use of drugs they got about $90 \%$ recoveries within a short period of time. These results influenced farmer to use more commercial aqua-drugs in controlling disease. Sometimes they applied drugs higher than recommended doses to get quick recovery. Normally in rural aquaculture, farmer used traditional chemicals in fish health management such as lime, salt, potassium permanganate, sumithion, melathion, formalin and bleaching powder. But they did not get better results than commercial drugs and chemicals. So, the farmer showed less interest to traditional drugs for disease control. The uncontrolled uses of drugs sometimes have got negative impact on fish health. Some pathogen evolved drug resistance ability due to unconscious and repeated use of drugs. It was not possible to control the disease in such condition. It was also found that in case of diseased Heteropneustes fossilis, farmers did not get any recovery.

The present study showed that Ciliated protozoan disease, Dropsy, Body hemorrhage, EUS, Gill rot disease, Tail rot disease, Anchor problem were identified. The most prevalent symptom of disease was red spot, followed by EUS, Dropsy, Edwardsiellosis, Red Spot Disease, Columnaris, Argulosis, Brachiomysis and White Spot disease. Similar conditions were also reported in the rural carp culture by several authors [16-19]. Most of the farmers of the selected areas used drugs and chemicals to control these types of disease. It meant that disease problem was one of the major concerns in aquaculture of the studied areas.

The aquaculture activities in Bangladesh are also influenced by a number of chemicals. It is important that policy makers, researchers, and scientists work together to address the issues of 
use of new commercial aqua-drugs and chemicals with the view to reduce their adverse impacts. Efforts should be made towards finding non-chemotherapeutic solutions to health management and disease control. Also, there is a need for better understanding of fish farm health management and disease prevention practices that could reduce the need for drug treatments.

\section{Conclusion}

Finally, the safest option is to reduce the harmful effects of chemical products in aquaculture by using less chemicals. During the field observation, some problems with the use of aqua medicinal products, including poor farmers' understanding of drug use, an insufficient time of withdrawal and some adverse effects on fish and human health, were found. In a cultural system, all medicines from an enterprise may not be appropriate for disease therapy. The study field has included fifty-one different types of aqua medicines and chemical products, of which ten are commonly used by farmers in the treatment of differing fish diseases. In order to overcome adverse pathologies in fish organs, the use of aqua-drugs and chemicals in ponds and ghers should be minimized. The overuse of aqua drugs and chemicals in fisheries has also shown a detrimental effect. Nevertheless, the appropriate authorities, policy makers, researchers and scientists should collaborate to reduce the harmful effects of aqua drugs and chemicals. This research will be useful for the market share of different drug and companies and taking precautionary steps against aqua drug use.

\section{References}

1. Ahmed GU, MAR Faruk, M Shamsuddin, MK Rahman (2014) Impact of Aqua-Drugs and Chemicals on Fish Health. In: M A Wahab, M A Shah, M S Hossain, M A R Barman and M E Haq (Eds). Advances of Fisheries Research in Bangladesh: 5th Fisheries Conference \& Research Fair 2012. Bangladesh Agricultural Research Council, Dhaka, Bangladesh Fisheries Research Forum, Dhaka, Bangladesh. Pp. 246.

2. Primavera JH, CR Lavilla Pitogo, MR Ladja, JM dela Pena (1993) A Survey of Chemical and Biological Products Used in Intensive Prawn Farms in the Philippines. Marine Pollution Bulletin 26(1): 35-40.

3. FDA (2001) Fish and Fisheries Products Hazards and Controls Guidance.

4. Faruk MAR, N Sultana, MB Kabir (2005) Use of Chemicals in Aquaculture Activities in Mymensingh Area, Bangladesh. Bangladesh Journal of Fisheries 29(1-2): 1 -10.

5. Shamsuzzaman MM and TK Biswas (2012) Aqua Chemicals in Shrimp Farm: A Study from South-west Coast of Bangladesh. Egyptian Journal of Aquatic Research 38(4): 275-285.
6. Shamsuddin M (2012) Impact of Aqua-Drugs and Chemicals on Health and Production of Fish. MS Thesis. Department of Aquaculture, Bangladesh Agricultural University, Mymensingh, Bangladesh.

7. Nupur JM (2010) Problems and Prospects of Shrimp Farming in Bangladesh. AIUB, Bus Econ Working Paper Series, No. 05.

8. Faruk MAR, MM Ali, ZP Patwary (2008) Evaluation of the Status of Use of Chemicals and Antibiotics in Freshwater Aquaculture Activities with Special Emphasis to Fish Health Management. Journal of Bangladesh Agricultural University 6: 381-390.

9. Subasinghe RP, U Barg, A Tacon (1996) Chemicals in Asian Aquaculture: Need, Usage, Issues, and Challenges. In: Arthur J R, C R Lavilla-Pitogo and R P Subhasinghe (eds), Use of Chemicals in Aquaculture in Asia. Southwest Asian Fisheries Development Center, Aquaculture department Tibauan, Iloilo, Philippines. Pp: 1-6.

10. Alam MA and MM Rashid (2014) Use of Aqua-Medicines and Chemicals in Aquaculture in Shatkhira District, Bangladesh, IOSR Journal of Pharmacy and Biological Sciences (IOSR-JPBS) 9(6): 5-9.

11. Sharker MR, KR Sumi, MJ Alam, MM Rahman, Zannatul Ferdous, MM Ali and MR Chaklader(2014) Drugs and Chemicals Used in Aquaculture Activities for Fish Health Management in Coastal Region of Bangladesh. International Journal of Life Sciences Biotechnology and pharma Research 3(4): 2250-2137.

12. Inglis V (1996) Antibacterial Chemotherapy in Aquaculture: Review of Practice, Associated Risks and Need for Action. In: Arthur JR, CR lavillaPitogo and RP Subasinghe (eds.) Use of Chemicals in Aquaculture in Asia. Southeast Asian Fisheries Development Centre, Aquaculture Department Tigbauan, Iloilo, Philippines, Pp. 7-22.

13. Sultana N (2004) Use of Chemicals in Aquaculture Activities in Mymensingh area. Department of Agriculture, Bangladesh Agricultural University, Mymensingh, Bangladesh 81.

14. Rasul MG, BC Majumdar, T Akter (2017) Aqua-Chemicals and Antibiotics Used in Freshwater Aquaculture of Sylhet, Bangladesh. Journal of Agricultural Science and Engineering 3(2): 20-26.

15. Chowdhury AA, MS Uddin, S Vaumik, A Asif (2015) Aqua Drugs and Chemicals Used in Aquaculture of Zakigonj Upazilla, Sylhet. Asian Journal of Medical Biology Research 1(2): 336-349.

16. Faruk MAR, MJ Alam, MMR Sarker, MB Kabir (2004) Status of Fish Disease and Health Management Practices in Rural Freshwater Aquaculture of Bangladesh. Pakistan Journal of Biological Science 7(12): 2092-2098.

17. DoF (2002) Fish Fortnight Compendium. Department of Fisheries, Matsha Bhaban, Dhaka. Pp: 44-45.

18. Mazid MA (2001) Fish Disease and Prevention. Bangladesh Fisheries Research Institute. Mymensingh. Pp. 36.

19. Amin MN (2000) Impact of Fish Diseases on Fish Culture in Northern Region of Bangladesh. Rural Development Academy, Bogra, Bangladesh 28. 


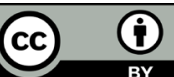

This work is licensed under Creative Commons Attribution 4.0 Licens

DOI: 10.19080/OFOAJ.2021.13.555869
Your next submission with Juniper Publishers will reach you the below assets

- Quality Editorial service

- Swift Peer Review

- Reprints availability

- E-prints Service

- Manuscript Podcast for convenient understanding

- Global attainment for your research

- Manuscript accessibility in different formats ( Pdf, E-pub, Full Text, Audio)

- Unceasing customer service

Track the below URL for one-step submission https://juniperpublishers.com/online-submission.php 